Article

\title{
Energy Efficiency Enhancement of Photovoltaics by Phase Change Materials through Thermal Energy Recovery
}

\author{
Ahmad Hasan *, Hamza Alnoman and Ali Hasan Shah \\ College of Engineering, United Arab Emirates University, Al Ain 15551, UAE; ha1987@uaeu.ac.ae (H.A.); \\ ali.hasan@uaeu.ac.ae (A.H.S.) \\ * Correspondence: ahmed.hassan@uaeu.ac.ae; Tel.: +971-555-454-069 \\ Academic Editors: Senthilarasu Sundaram and Tapas Mallick \\ Received: 12 June 2016; Accepted: 29 July 2016; Published: 28 September 2016
}

\begin{abstract}
Photovoltaic (PV) panels convert a certain amount of incident solar radiation into electricity, while the rest is converted to heat, leading to a temperature rise in the PV. This elevated temperature deteriorates the power output and induces structural degradation, resulting in reduced PV lifespan. One potential solution entails PV thermal management employing active and passive means. The traditional passive means are found to be largely ineffective, while active means are considered to be energy intensive. A passive thermal management system using phase change materials (PCMs) can effectively limit PV temperature rises. The PCM-based approach however is cost inefficient unless the stored thermal energy is recovered effectively. The current article investigates a way to utilize the thermal energy stored in the PCM behind the PV for domestic water heating applications. The system is evaluated in the winter conditions of UAE to deliver heat during water heating demand periods. The proposed system achieved a $\sim 1.3 \%$ increase in PV electrical conversion efficiency, along with the recovery of $\sim 41 \%$ of the thermal energy compared to the incident solar radiation.
\end{abstract}

Keywords: photovoltaics (PV); phase change material (PCM); thermal management; water heating; energy recovery

\section{Introduction}

The most efficient photovoltaic (PV) cells convert up to $27.6 \%$ of incoming solar radiation into electricity based on PV cell material [1,2], while the remaining more than $72 \%$ is reflected or converted into heat [3,4]. The incident energy converted into heat leads to elevated PV temperatures [5]. The PV temperature varies depending on the incoming solar radiation intensity $(G)$, ambient temperatures $\left(T_{\mathrm{amb}}\right)$, inclination of the PV panel, wind speed $\left(V_{\mathrm{w}}\right)$, mounting scheme of the panel, partial shading, dust accumulation and faults conditions in the panels [6,7]. The increased PV temperature consequently reduces the open circuit voltage [8], although a marginal increase in current [9] also occurs, with a net effect of a drop in PV power $[8,10]$. The temperature-induced power drop has been extensively studied and temperature-based power drop coefficients $\left(T_{\mathrm{C}}\right)$ ranging from $0.3 \% /{ }^{\circ} \mathrm{C}$ to $0.5 \% /{ }^{\circ} \mathrm{C}$ are determined, based on the cell technology used [11-14]. The $T_{\mathrm{C}}$ value may further increase over time due to thermal annealing depending on the cell operation conditions [15].

The effects of increased temperature on PV lifespan are reviewed in [16], where it was concluded that PV cells degrade faster in hot climates due to long-term thermal ageing caused by their elevated operating temperatures [17]. Additionally the PV panels lose structural integrity due to delamination caused by prolonged operations under elevated temperatures [18]. The conventional PV cooling techniques rely on active (air or water) circulation and passive air circulation, comprehensively reviewed by [19]. This work concludes that passive cooling (natural ventilation) is not an optimum 
option as the PV temperatures can still rise up to $70^{\circ} \mathrm{C}$. Active cooling can limit the temperature within $30^{\circ} \mathrm{C}$, however it consumes tremendous amounts of power through the use of fans or pumps which may override the potential benefits achieved by cell cooling.

A novel method was introduced to cool the PV panels by employing phase change materials (PCMs) on a model PV [20]. Various PCMs were characterized and a selection criteria was developed for their intended use in relation to PV cooling in outdoor ambient conditions [21]. The so-called photovoltaic-phase change materials (PV-PCM) system was evaluated for different PCM containment options [22] and a combination of PCMs with different melting points [23] which were then tested under various solar radiation intensities indoors [24] resulting in effective temperature control. The PCM cooling performance was further enhanced by inserting internal metallic fins which yielded improved PCM melting and solidification due to enhanced thermal conductivity. Conclusively, the PV-PCM technology have been proved to be effective in limiting temperature rise and increasing the performance of PV devices under single Sun [25] as well as low solar radiation concentration [26]. The PV-PCM technology has been tested in different climatic conditions [27] concluding that such technology is found to be more effective in warmer climates. Although the technology is effective in PV cooling as reviewed in detail by [28], it is still not commercially viable [29] unless the thermal energy part can be stored. Temperature regulation and electrical performance enhancement using PV-PCM technology is reviewed comprehensively by [30] emphasizing a need for more research on optimization of heat extraction and utilization.

The current research further enhances previous findings by investigating the extraction of heat stored in PCM and utilizing it for water heating applications. The article presents experimental results in order to quantify the electrical efficiency improvement and thermal energy benefits for water heating using the PV-PCM technology.

\section{Methodology}

The research methodology consists of the thermo-physical characterization of the PCM and integration of PCM into PV for its passive cooling. The PCM is characterized by differential scanning calorimetry (DSC) to confirm its thermos-physical properties. The PCM is encapsulated at the back of the PV to study its cooling effect and thermal energy storage capability. The cooling effect is quantified by the temperature changes in PV achieved by the presence of the PCM on the front and back surfaces of the PV. The thermal energy storage by the PCM is determined by changes in temperature and physical state (solid-liquid) of the PCM. The thermal energy stored in PCM is extracted by water circulation. The useful thermal energy gain by the water is calculated by changes in (averaged) water temperatures in the storage tank. The enhanced PV power due to the PV cooling is calculated by measuring the open circuit voltage and short circuit current of the respective PVs. Finally, an energy balance is carried out by comparing the solar gains by PV to the sum of electrical energy produced by PV, heat losses by PV, and heat stored in PCM behind PV. The heat stored in PCM is eventually compared with useful energy gain by the water circulated behind the PV containing the PCM.

\subsection{Experimental Setup}

Polycrystalline EVA-encapsulated PV panels with dimension of $53 \mathrm{~cm} \times 63 \mathrm{~cm}$, rated capacity of $40 \mathrm{~W}$ and module efficiency of $15 \%$ were tested outdoors facing south at the latitude of Al Ain $\left(24.1^{\circ} \mathrm{N}, 55.8^{\circ} \mathrm{E}\right)$. The electrical performance of the modules was confirmed by measuring the open circuit voltage $\left(V_{\mathrm{oc}}\right)$ and short circuit current $\left(I_{\mathrm{sc}}\right)$ prior to inclusion of the PCM in the panels. One PV panel (without PCM) was treated as reference and the other two were connected to internally finned containers filled with solid PCM using epoxy resin glue. The containers and internal fins were fabricated from a $4 \mathrm{~mm}$ thick sheet of aluminum alloy (1050A). A tubular $(1 \mathrm{~cm}$ internal diameter) metallic heat exchanger fabricated from the same alloy was embedded in the container to circulate water as heat transfer fluid, as shown in Figure 1. 


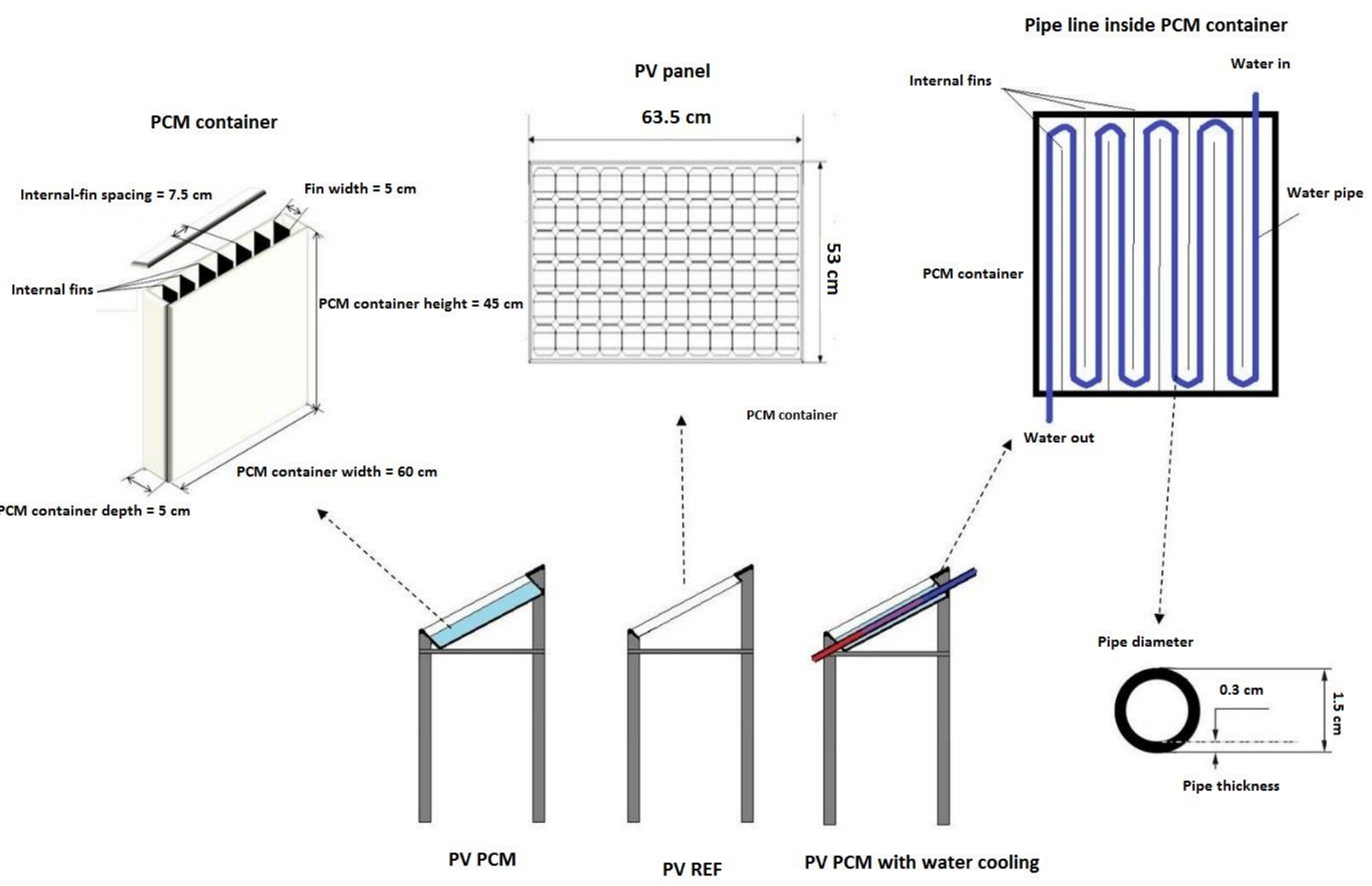

Figure 1. Construction of integrated photovoltaic phase change material (PV-PCM) system and metallic pipe heat exchanger immersed inside PCM container 
$50 \mathrm{~L}$ of water were contained in a polyethylene container with a thermal conductivity of 0.33-0.52 W. $\mathrm{m}^{-1} \cdot \mathrm{K}^{-1}$ [31]. Upon PCM melting, water was circulated from the PV-PCM container through insulated polymer pipes with thermal insulation of $1.2-3.0 \mathrm{Km}^{2} \cdot \mathrm{W}^{-1}$ at a flow rate of $0.027 \mathrm{~L} / \mathrm{s}$ to remove stored heat in the melted PCM. Multiple t-type copper-constantan thermocouples tested in an ice-bath with a measurement error of $\pm 0.3^{\circ} \mathrm{C}$ were installed on the three PV systems as shown in Figure 2. The thermocouples covered the front PV surface, back PV surface, inside the PCM and inside the water tank. The thermocouples were positioned on the front surface and were shielded from direct irradiation using a strong tape. A self-powered pyrometer with $0.20 \mathrm{mV}$ per $\mathrm{Wm}^{-2}$ sensitivity and $\pm 5 \%$ calibration uncertainty [32] was installed at the latitude angle of the site $\left(24.1^{\circ} \mathrm{N}, 55.8^{\circ} \mathrm{E}\right)$ to measure solar radiation intensity $(G)$. A weather station with temperature accuracy of $\pm 1^{\circ} \mathrm{C}$ [33] was installed to measure ambient temperature $\left(T_{\mathrm{amb}}\right)$ and wind speed $\left(V_{\mathrm{w}}\right)$. All the sensors were connected to a National Instruments (NI) compact Rio to log the data as shown in schematic of the experimental set up in the Figure 2. The measurement uncertainties for all the devices are listed in Table 1.

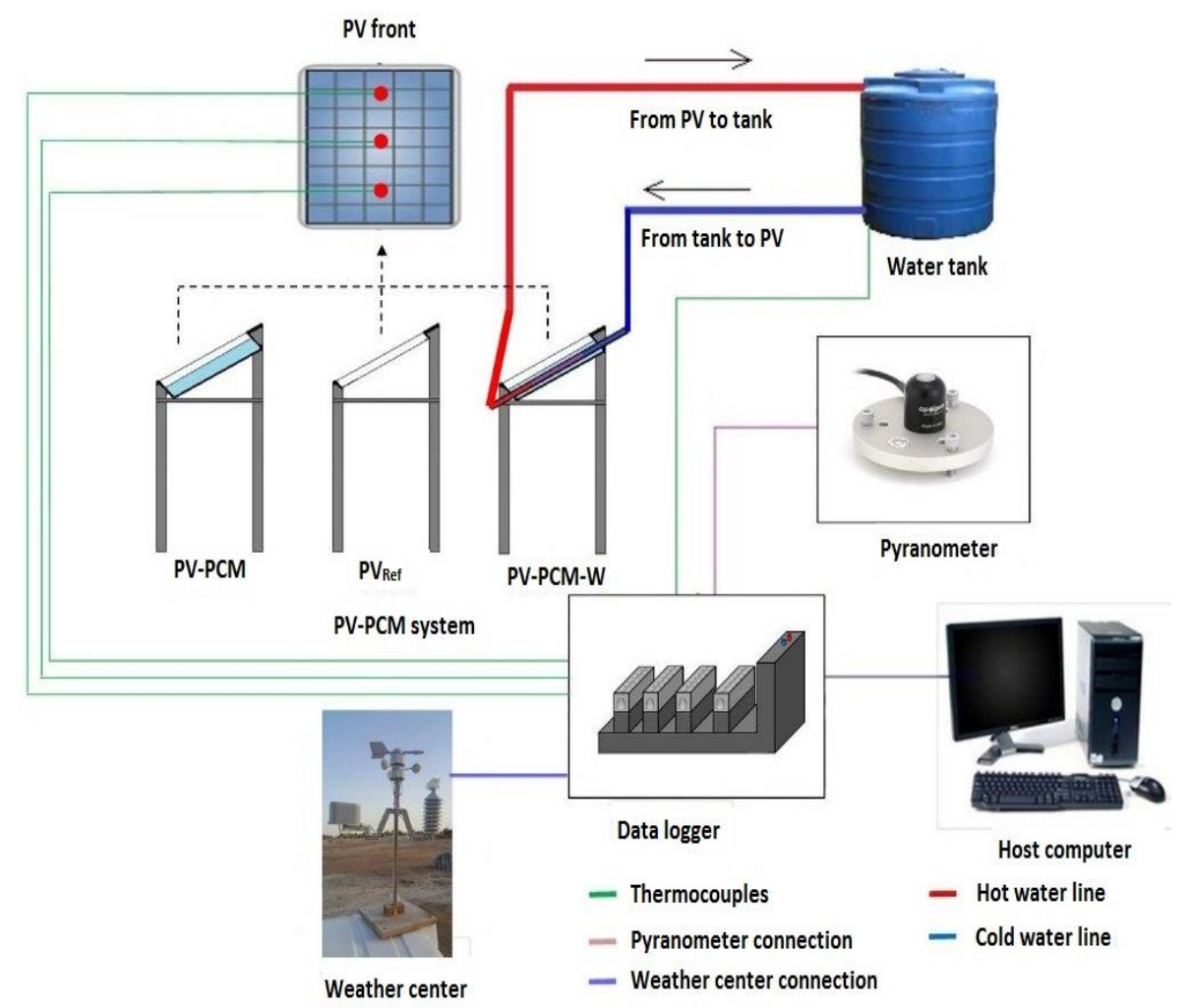

Figure 2. Experimental setup consisting of PV-reference, PV-PCM, and PV-PCM-W, water tank, data logger, weather station, Pyranometer and desktop computer for the outdoor experiment for consecutive 3 days from 30 January 2015 to 2 February 2015.

Table 1. Accuracies and measurement ranges of the devices used in experiments for weather data, temperature and PV performance measurements and data acquisition.

\begin{tabular}{ccccc}
\hline Measurement Parameter & Device & Model & Measurement Range & Accuracy \\
\hline Solar radiation [34] & Apogee pyranometer & SP-110 & 36-1120 nm & $\pm 1 \%$ \\
Data acquisition [35] & NI-Compact Rio & 9073 & NA (Not Applicable) & $\pm 0.02 \%$ \\
Current [36] & NI-Analogue module & 9227 & 5 Arms & $\pm 0.01 \%$ \\
Surface temperature [37] & Ni-Analogue module & 9213 & $-75-250{ }^{\circ} \mathrm{C}$ & $\pm 1 \%$ \\
Ambient temperature [38] & Starmeter weather station & WS1041 & $-40-60{ }^{\circ} \mathrm{C}$ & $\pm 1 \%$ \\
Wind speed [38] & Starmeter weather station & WS1041 & $0-50 \mathrm{~m} \cdot \mathrm{s}^{-1}$ & $\pm 1 \%$ \\
Voltage [39] & NI-Analogue module & 9221 & $-60-60 \mathrm{~V}$ & $\pm 0.25 \%$ \\
\hline
\end{tabular}




\subsection{Experimental Procedures}

The PCM was characterized through differential scanning calorimetry (DSC) to verify its thermo-physical properties given in Table 2 [40-43]. The PCM was filled as liquid (10.2 L) in the containers attached to the PV and subsequently cooled until it completely solidified. The solidified PCM left a $7 \mathrm{~cm}$ free space on top intended to accommodate volume expansion during PCM melting. The experiments were conducted for three consecutive days from 30 January 2015 to 2 February 2015 and same PCM solid state at the start of experiments were assured for each day. Water circulation was triggered every day upon PCM complete melting at 13:00 and was stopped upon complete heat removal at 16:00. The data was logged for the reference PV, the PV with PCM (PV-PCM) and PV-PCM with water circulation (PV-PCM-W) with a time step of $5 \mathrm{~min}$.

Table 2. Thermo-physical properties of PCM, metallic and bonding materials used in the experiments in solid state.

\begin{tabular}{|c|c|c|c|c|c|c|c|c|}
\hline Properties & $\begin{array}{c}\text { Melting } \\
\text { Point }\left({ }^{\circ} \mathrm{C}\right)\end{array}$ & $\begin{array}{l}\text { Congealing } \\
\text { Point }\left({ }^{\circ} \mathrm{C}\right)\end{array}$ & $\begin{array}{c}\text { Latent Heat } \\
(\mathrm{kJ} / \mathrm{kg})\end{array}$ & $\begin{array}{c}\text { Specific Heat } \\
\text { Capacity } \\
(\mathrm{kJ} / \mathrm{kg} \cdot \mathrm{K})\end{array}$ & $\begin{array}{c}\text { Heat } \\
\text { Conductivity } \\
(\mathrm{W} / \mathrm{m} \cdot \mathrm{K})\end{array}$ & $\begin{array}{l}\text { Density } \\
\text { (kg/L) }\end{array}$ & $\begin{array}{l}\text { Volume } \\
\text { Expansion }\end{array}$ & $\begin{array}{c}\text { Flash } \\
\text { Point }\left({ }^{\circ} \mathrm{C}\right)\end{array}$ \\
\hline PCM RT42 [40] & $38-43$ & $43-37$ & $145 \% \pm 7.5 \%$ & 2 & 0.2 & 0.88 & $12.5 \%$ & 186 \\
\hline Aluminum [41] & 650 & NA & NA & 0.91 & 222 & 2.71 & $24 \times 10^{-6} / \mathrm{K}$ & NA \\
\hline Epoxy Resin [43] & 130 & NA & NA & NA & 1.26 & 2.09 & $34 \times 10^{-6} / \mathrm{K}$ & 350 \\
\hline
\end{tabular}

\section{Results and Discussion}

\subsection{Weather Data}

Figure 3 shows global solar radiation intensity $(G)$ and wind speed $\left(V_{\mathrm{w}}\right)$ during the three days of the experiment.

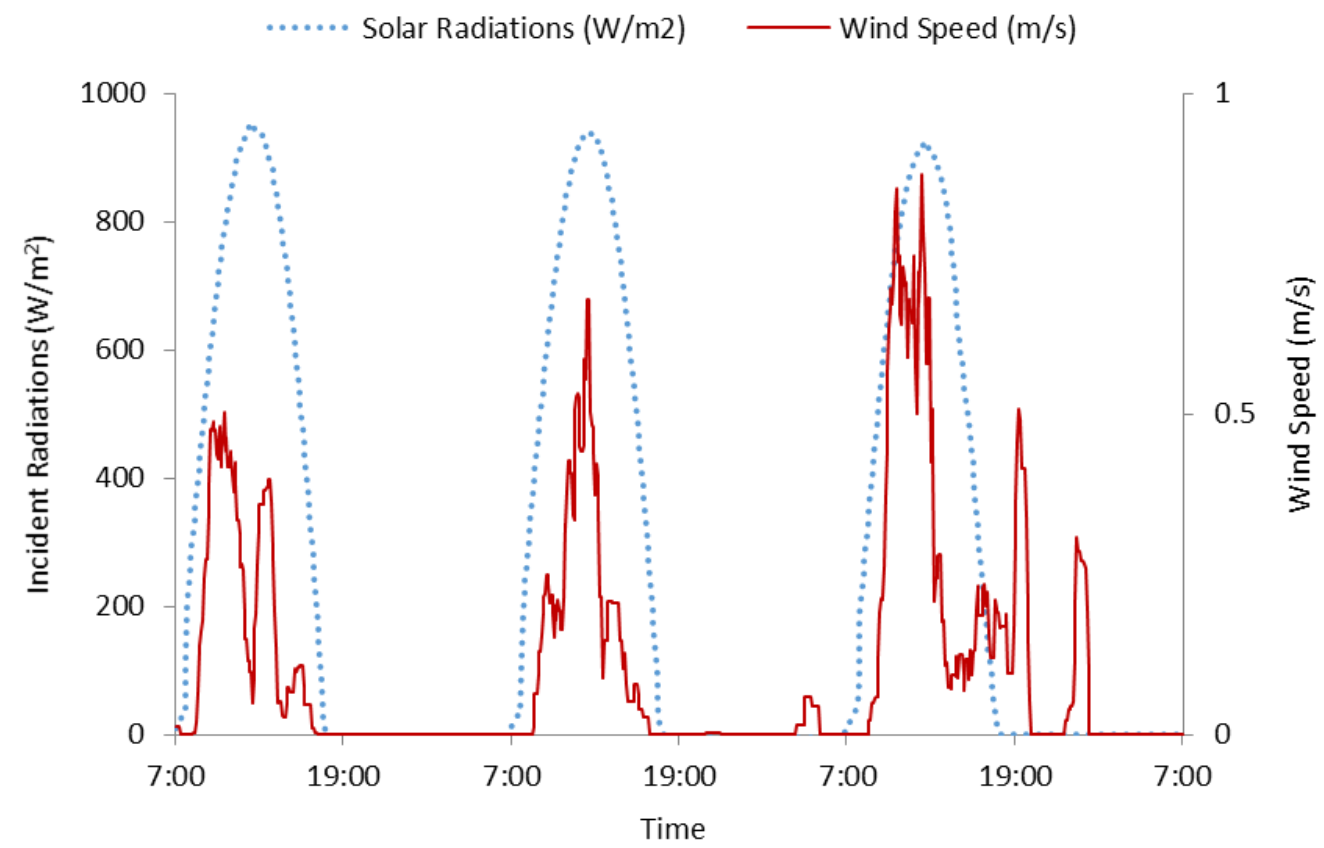

Figure 3. The measured solar irradiance $(G)$ and wind speed $\left(V_{\mathrm{w}}\right)$ data for consecutive 3 days from 30 January 2015 to 2 February 2015 at the site in Falaj Hazza Campus, UAE University, Al Ain, UAE.

It indicates that for all the three days, $G$ remained fairly stable with similar profile however with a slight difference in the peak as well as average hourly radiation intensity summarized in Table 3. 
Table 3. The measured average, peak and daily total data for solar radiation and wind speed for PV back and front surface for consecutive 3 days from 30 January 2015 to 2 February 2015 in Falaj Hazza Campus, UAE University, Al Ain, UAE.

\begin{tabular}{|c|c|c|c|c|c|c|c|c|}
\hline \multirow{3}{*}{ Day } & \multicolumn{4}{|c|}{ Wind Speed $(\mathrm{m} / \mathrm{s})$} & \multicolumn{2}{|c|}{$\begin{array}{l}\text { Solar Radiation } \\
\text { Intensity }\left(\mathrm{W} / \mathrm{m}^{2}\right)\end{array}$} & \multicolumn{2}{|c|}{$\begin{array}{c}\text { Daily Total } \\
\text { Radiation (Wh/day) }\end{array}$} \\
\hline & \multicolumn{2}{|c|}{ Average at the PV } & \multicolumn{2}{|c|}{ Peak at the PV } & \multirow[b]{2}{*}{ Average } & \multirow[b]{2}{*}{ Peak } & \multirow[b]{2}{*}{ Available } & \multirow[b]{2}{*}{ Absorbed } \\
\hline & $\begin{array}{c}\text { Front } \\
\text { Surface }\end{array}$ & $\begin{array}{c}\text { Back } \\
\text { Surface }\end{array}$ & $\begin{array}{c}\text { Front } \\
\text { Surface }\end{array}$ & $\begin{array}{c}\text { Back } \\
\text { Surface }\end{array}$ & & & & \\
\hline 1 & 0.08 & 0.04 & 0.50 & 0.15 & 595 & 960 & 1657 & 1256 \\
\hline 2 & 0.08 & 0.04 & 0.68 & 0.21 & 582 & 940 & 1634 & 1234 \\
\hline 3 & 0.17 & 0.09 & 0.87 & 0.26 & 552 & 920 & 1540 & 1140 \\
\hline
\end{tabular}

For all the three days, the speed $\left(V_{\mathrm{w}}\right)$ remained very low with a peak and average values of $0.9 \mathrm{~m} / \mathrm{s}$ and $0.2 \mathrm{~m} / \mathrm{s}$. The airflow around the PV surface caused by windy conditions induces natural convection heat losses empirically predicted by Tiwari [44]. The approach is based on combined convective and radiative heat loss coefficient $(h)$ applicable to air velocities $\leq 3 \mathrm{~m} / \mathrm{s}$ given by Equation (1):

$$
h=5.7+3.8 V_{w}
$$

The $h$ calculated through Equation (1) ranges between $7.6-9 \mathrm{~W} / \mathrm{m}^{2} \cdot \mathrm{K}$ at peak and $6-6.34 \mathrm{~W} / \mathrm{m}^{2} \cdot \mathrm{K}$ on average for the front surface for the three days. The $h$ value calculated for the back surface remained lower than that of the front surface, ranging from $6.3-6.7 \mathrm{~W} / \mathrm{m}^{2} \cdot \mathrm{K}$ at peak and $-0.58-6 \mathrm{~W} / \mathrm{m}^{2} \cdot \mathrm{K}$ on average. It can be noticed that on average the $h$ value did not differ substantially between the front and back PV surface. However the peak $h$ value at the PV back surface remained substantially lower than at the front surface. The substantially lower peak $h$ value at the back surface yielded lesser heat loss and resulted in a substantial temperature rise at the back compared to the surface of the reference PV, noticeable in Figures 4 and 5.

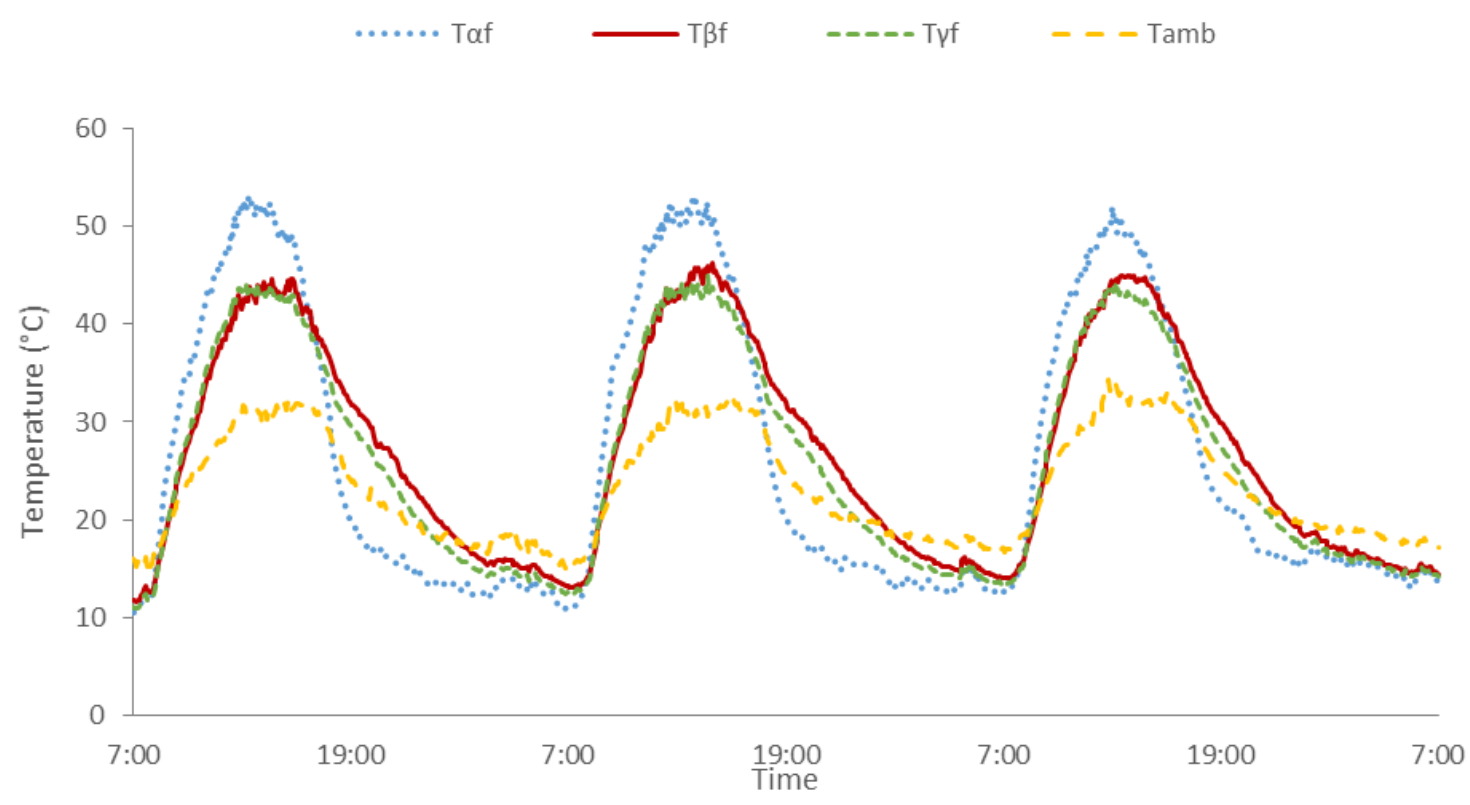

Figure 4. The measured temperatures at front surfaces of reference PV panel $\left(T_{\alpha \mathrm{f}}\right), \mathrm{PV}-\mathrm{PCM}$ panel $\left(T_{\beta f}\right)$ PV-PCM-water circulation $\left(T_{\gamma \mathrm{f}}\right)$ and ambient temperature $\left(T_{\mathrm{amb}}\right)$ for consecutive 3 days from 30 January 2015 to 2 February 2015 at the site of system deployment. 


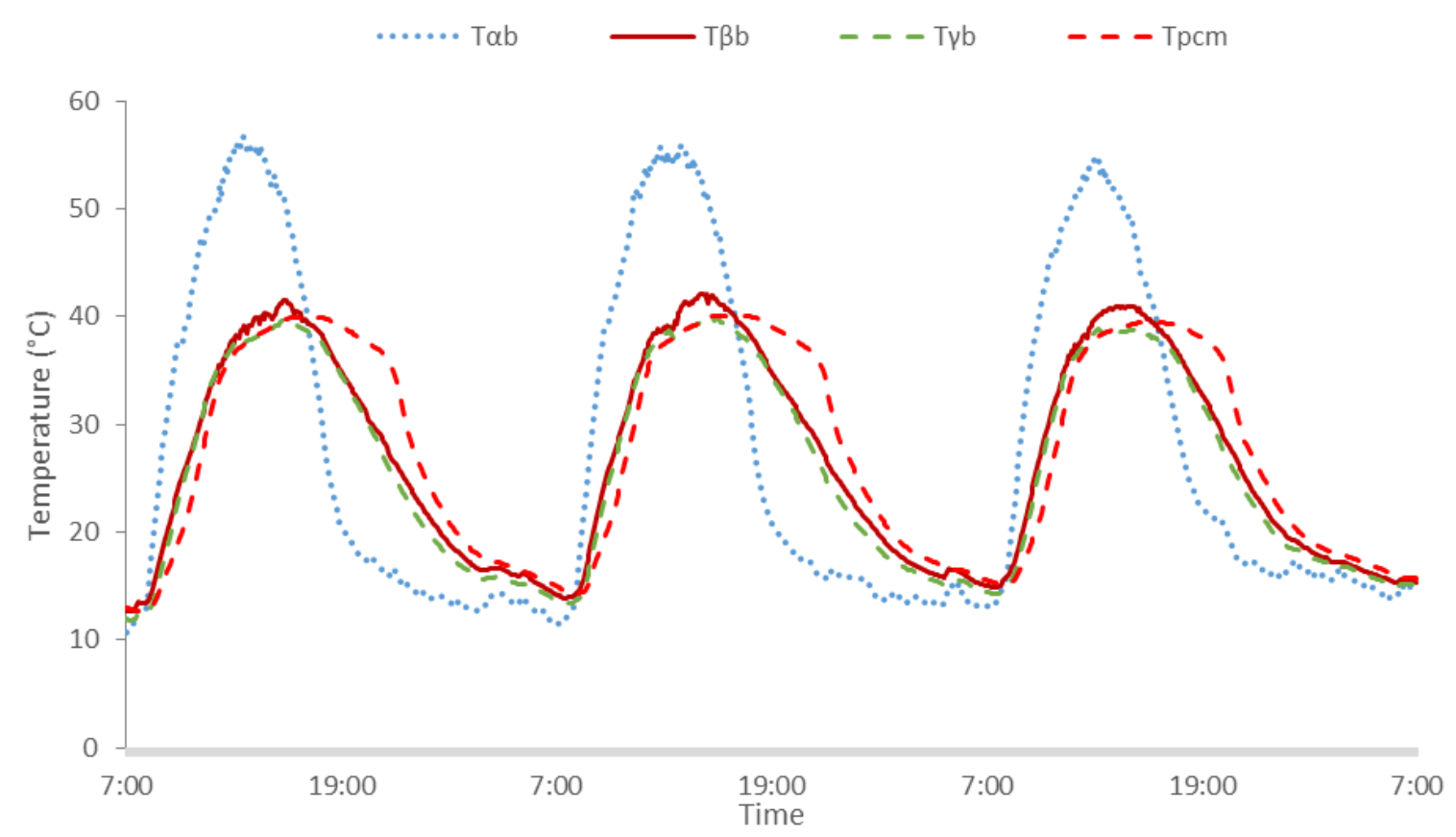

Figure 5. The measured temperatures at back surfaces of reference PV panel ( $\left.T_{\alpha b}\right), P V-P C M\left(T_{\beta b}\right)$, PV-PCM-water flow $\left(T_{\gamma \mathrm{b}}\right)$ and inside phase change material temperature $\left(T_{\mathrm{pcm}}\right)$ for consecutive 3 days from 30 January 2015 to 2 February 2015 at the site of system deployment.

The lower $h$ values indicate that natural convection cannot effectively cool the PV at this site, thereby resulting in higher PV temperatures that eventually affects the PV electrical conversion efficiency. However, lower $h$ values can be potentially beneficial once the concept of thermal energy storage and recovery is introduced in the PV, as it would minimize heat losses. The solar radiation absorbed by the PV $\left(Q_{\text {pv }}\right)$ depends on the surface area $(A)$ and cleanliness of the PV surface represented by dusting coefficient $0.77\left(d_{c}\right)$ and the absorptance $(\alpha)$ of the PV panel as given by Equation (2):

$$
Q_{\mathrm{PV}}=G \times A \times d_{\mathrm{c}} \times \alpha
$$

The $Q_{\mathrm{pv}}$ values are summarized in Table 3, which indicates that PV receives reasonably different amount of radiation each day, with a highest deviation amongst the three days of $9.2 \%$.

\subsection{Temperature Drop}

The measured front surface temperatures of the reference PV $\left(T_{\alpha}\right)$, PV-PCM $\left(T_{\beta}\right)$ and PV-PCM with water circulation $\left(T_{\gamma}\right)$ along with ambient temperature $\left(T_{\mathrm{amb}}\right)$ are presented in Figure 4 . Figure 4 shows that at start of the experiment, $T_{\mathrm{amb}}$ was $16^{\circ} \mathrm{C}$, which increased with a stable gradient reaching peak of $32{ }^{\circ} \mathrm{C}$ at 13:00 for day 1 . It can be observed that $T_{\mathrm{amb}}$ remained at all times below the PCM melting initiation temperature $\left(T_{\mathrm{m}}\right)$ of $37^{\circ} \mathrm{C}$ indicating that $T_{\mathrm{amb}}$ alone would not trigger PCM melting. At the start of the experiment, $T_{\alpha \mathrm{f}}, T_{\beta \mathrm{f}}$ and $T_{\gamma \mathrm{f}}$ were almost the same $\left(11^{\circ} \mathrm{C}\right)$ being substantially lower than $T_{\mathrm{m}}$, indicating that PCM contained at the PV back was in solid state at the start of the experiment which was also confirmed by visual inspection. As radiation hits the PV at 7:00 am, the temperature started to increase for the three PV modules however each with a different gradient. As expected, $T_{\alpha \mathrm{f}}$ exhibited a higher gradient of rise followed by $T_{\beta f}$ and $T_{\gamma \mathrm{f}}$ with a time lag caused by a higher thermal inertia achieved by the inclusion of the PCM (in PV-PCM and PV-PCM-W) compared to the PV alone. The $T_{\alpha \mathrm{f}}$ reached its peak at $53{ }^{\circ} \mathrm{C}$ at 1:25 PM while $T_{\beta \mathrm{f}}$ and $T_{\gamma \mathrm{f}}$ remained below $44{ }^{\circ} \mathrm{C}$ at the same time yielding a drop of $9{ }^{\circ} \mathrm{C}$ at peak. The average $T_{\alpha f}$ reached $38.5^{\circ} \mathrm{C}$, followed by $33.5^{\circ} \mathrm{C}$ and $33.4{ }^{\circ} \mathrm{C}$ in the cases of $T_{\beta \mathrm{f}}$ and $T_{\gamma \mathrm{f}}$, respectively, rendering an average temperature drop of $5^{\circ} \mathrm{C}$ compared to the PV without PCM. The water circulation at 13:00 induced a slight additional temperature drop 
observed in $T_{\gamma \mathrm{f}}$. A similar trend in temperature rise was observed for the remaining two days with slightly different magnitudes. The different $T_{\alpha f}, T_{\beta f}$ and $T_{\gamma \mathrm{f}}$ values resulted in different amounts of heat being discarded to the environment through natural convection and radiation, quantified by Equations (3)-(5):

$$
\begin{aligned}
& Q_{\mathrm{l \alpha f}}=h \times A \times\left(T_{\alpha \mathrm{f}}-T_{\mathrm{amb}}\right) \\
& Q_{\mathrm{l} \beta \mathrm{f}}=h \times A \times\left(T_{\beta \mathrm{f}}-T_{\mathrm{amb}}\right) \\
& Q_{\mathrm{l \gamma f}}=h \times A \times\left(T_{\gamma \mathrm{f}}-T_{\mathrm{amb}}\right)
\end{aligned}
$$

where $Q_{1}$ and $A$ represent the heat loss and cross-section area of the PV panel, respectively. Applying Equations (3)-(5), on the measured data, it is found that the front surface of the reference PV discarded $380 \mathrm{Wh} /$ day to ambient, which was reduced to $242 \mathrm{Wh} /$ day (for PV-PCM) and $232 \mathrm{Wh} /$ day for PV-PCM with water flow.

The $T_{\mathrm{pcm}}$ along with the back surface temperatures of the reference PV $\left(T_{\alpha \mathrm{b}}\right)$, PV-PCM $\left(T_{\beta \mathrm{b}}\right)$ and PV-PCM with water circulation $\left(T_{\gamma b}\right)$ are presented in Figure 5. All the temperatures, $T_{\alpha b}, T_{\beta b}$, $T_{\gamma \mathrm{b}}$ and $T_{\mathrm{pcm}}$ were almost the same at the start of the experiment, however they differed in transient temperature rise afterwards, reaching peak values of $57^{\circ} \mathrm{C}, 39^{\circ} \mathrm{C}, 38^{\circ} \mathrm{C}$ and $42{ }^{\circ} \mathrm{C}$, respectively. It can be see that inclusion of the PCM caused a delay in the temperature rise compared to the PV alone due to the increased thermal inertia of the system caused by the PCM's latent heat absorption. The peak temperature drop was $19^{\circ} \mathrm{C}$ (from $57^{\circ} \mathrm{C}$ to $38^{\circ} \mathrm{C}$ ). Taking the average of the temperature curves, it was noted that an average temperature drop of $10^{\circ} \mathrm{C}$ was achieved at the back surface of PV-PCM for day 1 , attributed to the heat stored in the PCM. The reduced $T_{\beta b}, T_{\gamma b}$ prevented heat loss from the back surface of the PV-PCM compared to the reference PV calculated by the combined convection and radiation heat loss Equations (6)-(8) below:

$$
\begin{aligned}
& Q_{\mathrm{lab}}=h \times A \times\left(T_{\alpha \mathrm{b}}-T_{\mathrm{amb}}\right) \\
& Q_{1 \beta \mathrm{b}}=h \times A \times\left(T_{\beta \mathrm{b}}-T_{\mathrm{amb}}\right) \\
& Q_{1 \gamma \mathrm{b}}=h \times A \times\left(T_{\gamma \mathrm{b}}-T_{\mathrm{amb}}\right)
\end{aligned}
$$

Heat losses at the back of the PV surface are calculated by applying Equations (6)-(8) on the experimental data from Figure 5. The heat losses dropped from $409 \mathrm{Wh} /$ day for the reference PV $\left(Q_{1 \alpha b}\right)$ to $143 \mathrm{Wh} /$ day for both PV-PCM and PV-PCM-W ( $Q_{1 \beta b}$ and $Q_{1 \gamma b}$, respectively). By combining the front and back surface heat losses, the total heat loss dropped from $794 \mathrm{Wh} /$ day (reference PV) to $385 \mathrm{Wh} /$ day in case of PV-PCM and $375 \mathrm{Wh}$ /day for PV-PCM-W preventing a heat loss of $409 \mathrm{Wh} /$ day and $419 \mathrm{Wh}$ /day, respectively.

Heat losses prevented by the PCM alone are calculated by deducting the sensible heat stored in metallic parts in PV-PCM system calculated using Table 4 (53 Wh/day) [40,42,45]. The heat loss thereby prevented by the PCM dropped to $356 \mathrm{Wh} /$ day.

Table 4. Calculation of heat storage capacity and energy stored in PV-Ref, PV-PCM and PV-PCM-W for the experiment conducted for three consecutive days 30 January 2015 to 2 February 2015 at the site of system deployment in Falaj Hazza Campus, UAE University.

\begin{tabular}{ccccccc}
\hline Element & $\boldsymbol{\rho}\left(\mathbf{K g} / \mathbf{m}^{\mathbf{3}}\right)$ & $\left.\mathbf{C}_{\mathbf{p}} \mathbf{( J /} / \mathbf{k g} \cdot \mathbf{K}\right)$ & $\mathbf{d} \mathbf{( m )}$ & Area $\left.\mathbf{( m}^{\mathbf{2}}\right)$ & $\mathbf{H}(\mathbf{J} / \mathbf{k g})$ & $\mathbf{A} \times \mathbf{d} \times \boldsymbol{\rho} \times \mathbf{C p}(\mathbf{J} / \mathbf{K})$ \\
\hline Silicon PV cells [45] & 2330 & 677 & 0.0003 & 0.334 & NA & 158 \\
Polyester/Tedlar [45] & 1200 & 1250 & 0.0005 & 0.334 & NA & 250 \\
Glass face [45] & 3000 & 500 & 0.003 & 0.334 & NA & 1503 \\
Aluminum [42] & 2710 & 910 & 0.004 & 0.9728 & NA & 9596 \\
PCM sensible heat [40] & 880 & 2000 & 0.05 & 0.2968 & NA & 26118 \\
PCM latent heat [40] & 880 & NA & 0.05 & 0.2968 & 155000 & NA \\
\hline
\end{tabular}


It can be seen that the inclusion of a PCM reduced the PV temperature (Figures 4 and 5) while reducing heat losses. The novelty of the latent heat storage concept lies in reducing the heat losses by maintaining a lower temperature compared to sensible heat dissipation systems. The heat retention along with lower PV temperature has two benefits. The reduced temperature can increase the PV power output as discussed in Section 3.4, while the retained heat (solely due to heat loss prevention) can be utilized for water heating, as discussed in Section 3.3. The PV temperature drop along with heat retention and utilization by PCM is in agreement with the reported literature findings [46].

The retained heat was consumed in melting the PCM which can be determined by observing changes in PCM temperature $\left(T_{\mathrm{pcm}}\right)$. Figure 5 shows that $T_{\mathrm{pcm}}$ reached $37^{\circ} \mathrm{C}$ (start of PCM melting) at 11:00, increasing to $42{ }^{\circ} \mathrm{C}$ (end of PCM melting) at 12:40 and continued to rise to $43^{\circ} \mathrm{C}$ at 13:00. This indicates that PCM had completely melted before 13:00 prior to triggering the water flow to remove the heat stored in the melted PCM to heat the water. At nighttime, the $T_{\mathrm{pcm}}$ dropped below $37^{\circ} \mathrm{C}$ (PCM solidification temperature) at $21: 00$ and reached the lowest value of $13^{\circ} \mathrm{C}$ by the morning. It indicates that the PCM had completely solidified before the start of the next day, which was also confirmed by visual inspection. Since the PCM showed complete phase change (melting and solidification), the energy stored can be calculated by assuming complete solid-liquid phase transition given by Equations (9)-(11):

$$
\begin{gathered}
Q_{\mathrm{s} \alpha}=\rho_{\alpha} V_{\alpha} C_{\mathrm{p} \alpha}\left(T_{\alpha \mathrm{i}}-T_{\alpha \mathrm{f}}\right) \\
Q_{\mathrm{s} \beta}=\rho_{\beta} V_{\beta} C_{\mathrm{p} \beta}\left(T_{\beta \mathrm{i}}-T_{\beta \mathrm{f}}\right)+\rho_{\mathrm{pcm}} V_{\mathrm{pcm}} L \\
Q_{\mathrm{s} \gamma}=\rho_{\gamma} V_{\gamma} C_{\mathrm{p} \alpha}\left(T_{\gamma \mathrm{i}}-T_{\gamma \mathrm{f}}\right)+\rho_{\mathrm{pcm}} V_{\mathrm{pcm}} L
\end{gathered}
$$

where $\rho, V, C_{\mathrm{p}}$ are density, volume and heat capacity, while subscripts $i$ and $f$ represent the initial and final state of the PCM. Heat absorbed by the reference PV $\left(Q_{\alpha}\right)$, PV-PCM $\left(Q_{\beta}\right)$ and PV-PCM-W $\left(Q_{\gamma}\right)$ calculated by Equations (9)-(11) are $15 \mathrm{kWh} /$ day, $418 \mathrm{Wh}$ /day and $429 \mathrm{Wh} /$ day, respectively. The heat stored ( $418 \mathrm{Wh} /$ day and $429 \mathrm{Wh} /$ day) is in close agreement to the prevented heat loss (409 Wh/day and $419 \mathrm{Wh}$ /day) by PV-PCM and PV-PCM-W, respectively, which proves the accuracy of our experiments.

\subsection{Useful Energy Gain for Water Heating}

In order to extract the thermal energy stored in the PCM, water at an initial temperature of $29^{\circ} \mathrm{C}$ was pumped into melted PCM at a flow rate of $0.027 \mathrm{~L} / \mathrm{s}$ starting from 13:00 (shown by arrows in Figure 6) till 16:00 with a total volume of $50 \mathrm{~L}$. The measured water temperature for the three days of the experiment is shown in Figure 6 . The initial $\sim 2{ }^{\circ} \mathrm{C}$ increase in water temperature at the start of the days is attributed to the heat exchange with the ambient. The water tank was insulated during the daytime and uninsulated at nighttime to allow the water self-cooling to be ready for the next day recirculation. The insulation was put on at 9:00 each day, which can be confirmed that after initial temperature rise, the water temperature remained stable until the pump was turned on. It can be observed that water temperature raised from $29^{\circ} \mathrm{C}$ to $38^{\circ} \mathrm{C}$ showing an increase of $9{ }^{\circ} \mathrm{C}$. The heat removed by circulating water $\left(Q_{\mathrm{w}}\right)$ applying sensible heat gain Equation (12):

$$
Q_{\mathrm{w}}=\rho_{\mathrm{w}} V_{\mathrm{w}} C_{\mathrm{pw}}\left(T_{\mathrm{wi}}-T_{\mathrm{wf}}\right)
$$

where $\rho_{\mathrm{w}}, V_{\mathrm{w}}, C_{\mathrm{pw}}, T_{\mathrm{wi}}$ and $T_{\mathrm{wf}}$ are the density, volume, specific heat capacity, initial temperature and final temperature for water, respectively. Applying Equation (12) it is calculated that $521 \mathrm{Wh} /$ day of thermal energy was stored in the water, representing $~ 41 \%$ of the incoming global radiation incident on the PV (1256 Wh/day) as presented in Table 3. 


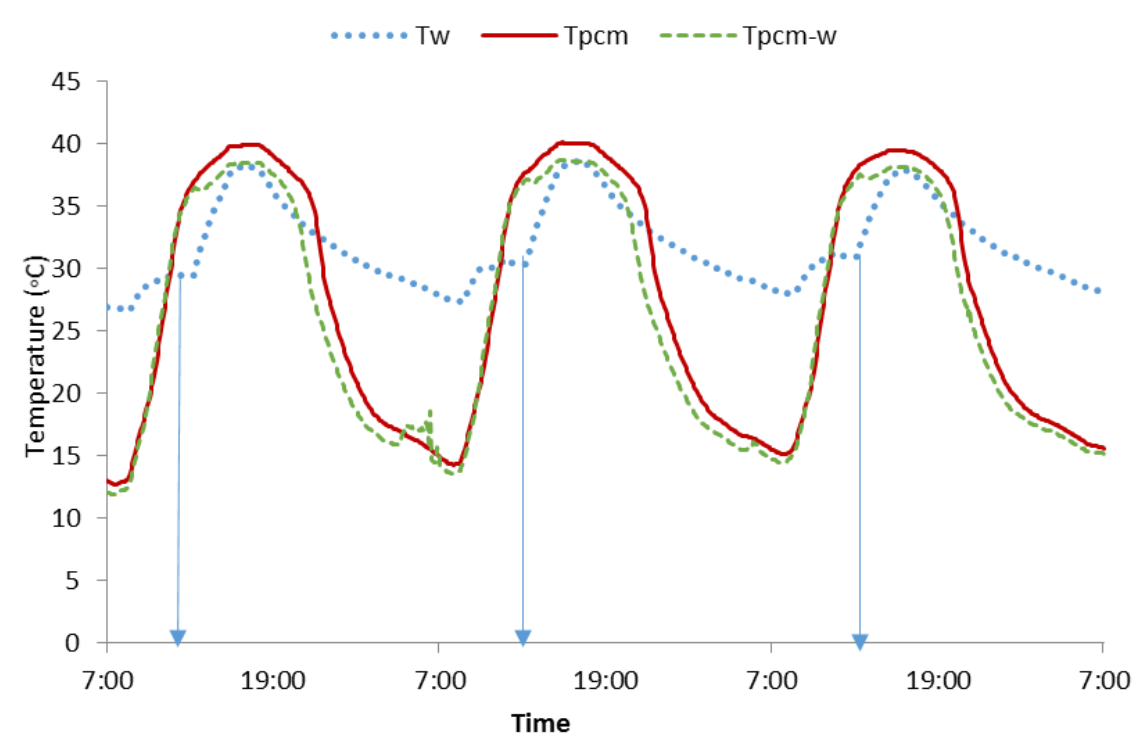

Figure 6. Average water temperature inside water tank $\left(T_{\mathrm{w}}\right)$, inside temperature of PCM $\left(T_{\mathrm{pcm}}\right)$ and inside temperature of PCM with water circulation $\left(T_{\mathrm{pcm}-\mathrm{w}}\right)$ for three consecutive days from 30 January 2015 to 2 February 2015 at the site of system deployment in Falaj Hazza Campus, UAE University.

\subsection{Improvement in PV Power Output}

The decrease in temperature reported in Section 3.2 has a positive effect on the PV voltage but a negative effect on current due to the decreased charge mobility. The measured $V_{\text {oc }}$ presented in Figure 7 shows that PV-PCM and PV-PCM-W maintained a higher $V_{\mathrm{oc}}$ compared to the reference PV. The peak $V_{\text {oc }}$ was recorded as $18.6 \mathrm{~V}$ for reference PV $\left(V_{\text {oc } \alpha}\right), 20.3$ volt for PV-PCM $\left(V_{\text {oc } \beta}\right)$ and $20.3 \mathrm{~V}$ for PV-PCM-W $\left(V_{\mathrm{oc} \gamma}\right)$. It indicates that inclusion of PCM yielded an $\sim 9 \%$ increase in $V_{\mathrm{oc}}$ by virtue of maintaining lower temperatures.

The $I_{\mathrm{sc}}$ presented in Figure 8 shows a relatively negligible difference amongst the three systems apart from that at the peak. The reference PV maintained a slight higher current $\left(I_{\mathrm{sc} \alpha}\right)$ compared to $\operatorname{PV}-\mathrm{PCM}\left(I_{\mathrm{sc} \beta}\right)$ and PV-PCM-W $\left(I_{\mathrm{sc} \gamma}\right)$ due to being at higher temperature.

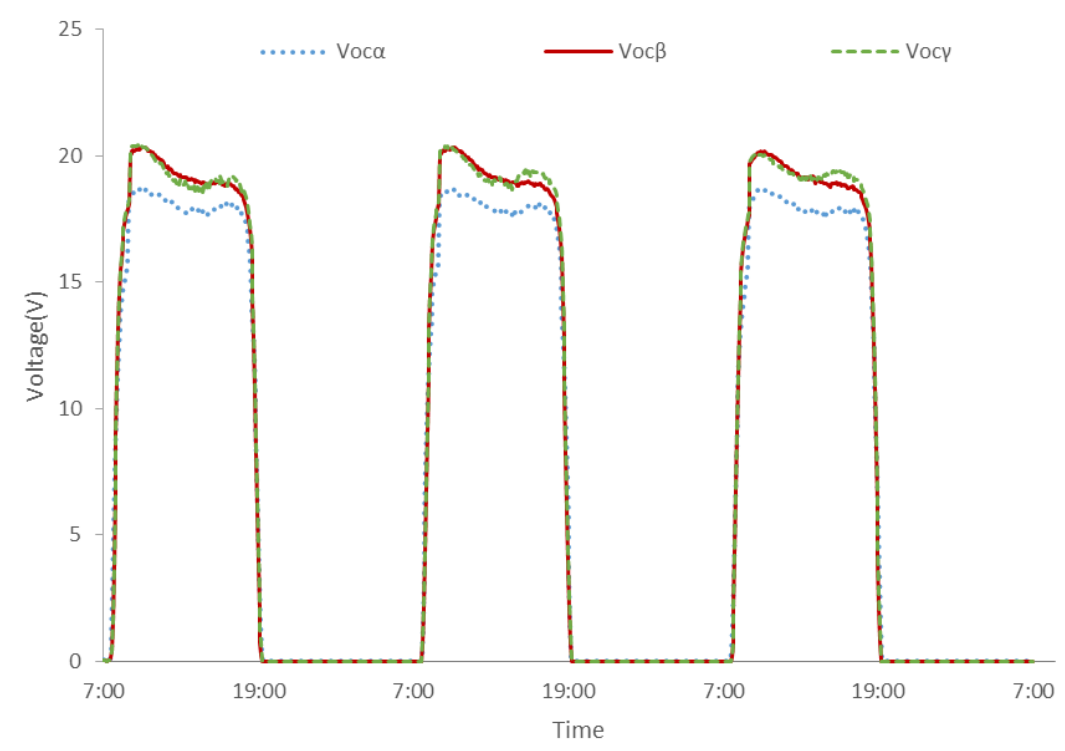

Figure 7. Open circuit voltage for PV $\left(V_{\mathrm{oc} \alpha}\right)$, PV-PCM $\left(V_{\mathrm{oc} \beta}\right)$ and PV-PCM-W $\left(V_{\mathrm{oc} \gamma}\right)$ for three consecutive days from 30 January 2015 to 2 February 2015 at the site of system deployment in Falaj Hazza Campus, UAE University, Al Ain, UAE. 


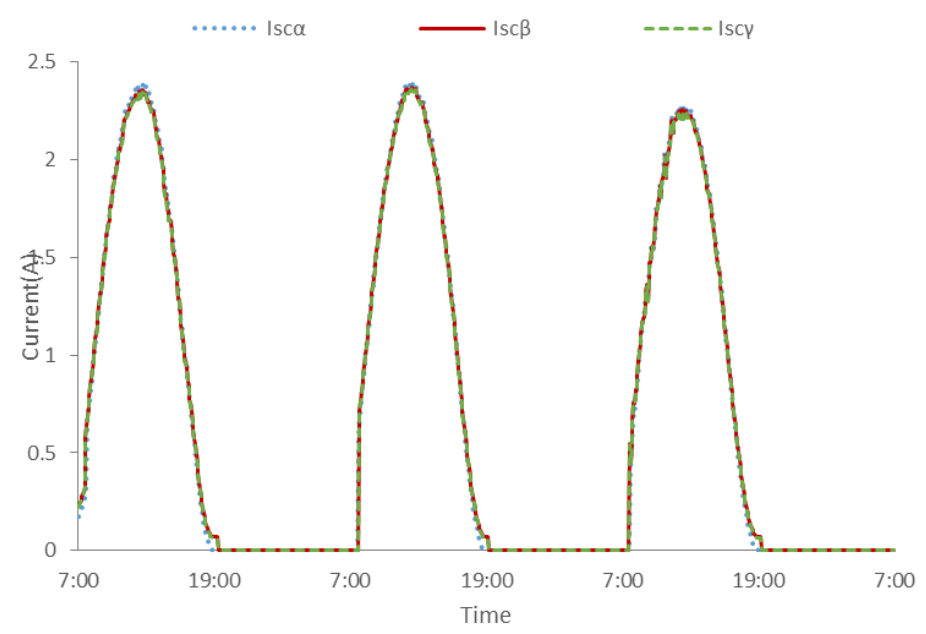

Figure 8. Short circuit current for PV $\left(I_{\mathrm{sc} \alpha}\right), \operatorname{PV}-\mathrm{PCM}\left(I_{\mathrm{sc} \beta}\right)$ and PV-PCM-W $\left(I_{\mathrm{sc} \gamma}\right)$ for three consecutive days from 30 January 2015 to 2 February 2015 at the site of system deployment in Falaj Hazza Campus, UAE University, Al Ain, UAE.

From recorded $V_{\mathrm{oc}}$ and $I_{\mathrm{sc}}$, the power produced by $\mathrm{PV}$ is calculated by applying the fill factor ( $F F$ ) correlation given by Equation (13):

$$
P=\left(V_{\mathrm{oc}} \times I_{\mathrm{sc}}\right) / F F
$$

where $P$ is the electrical power produced by the PV. The FF is considered to be constant $(0.7)$ deduced from PV data sheet. Figure 9 shows that inclusion of PCM produced higher peak power $\left(P_{\beta}=P_{\gamma}=34 \mathrm{~W}\right)$ compared to the reference PV $\left(P_{\alpha}=32 \mathrm{~W}\right)$ yielding an increase of $\sim 6.5 \%$. The average power produced by inclusion of PCM $\left(P_{\beta}=P_{\gamma}=20 \mathrm{~W}\right)$ was of $\sim 6 \%$ higher compared to that of the reference $\mathrm{PV}\left(P_{\gamma}=18.9 \mathrm{~W}\right)$. The total electrical energy produced increased from $272 \mathrm{Wh} /$ day for reference PV to $288 \mathrm{Wh} /$ day for the PV-PCM and PV-PCM-W (increase of $18 \mathrm{Wh} /$ day) indicating an increase of $6 \%$ (equivalent to increase in PV efficiency by 1.3\%). However since water was circulated behind the PV for heat extraction, the additional power would be needed to account for pressure drop in water circuit. The additional power consumed by the pump due to pressure drop in PV water circulation is calculated by assuming $10 \mathrm{~m}$ additional water head with a flow $0.027 \mathrm{~L} / \mathrm{s}$. It resulted in the additional shaft power of $4 \mathrm{~W}$ with total energy consumed being $12 \mathrm{Wh} /$ day as the water was circulated for three hours a day. The additional power required (12 Wh/day) is still lower than improved PV power output by PV cooling (18 Wh/day) so the concept is justified.

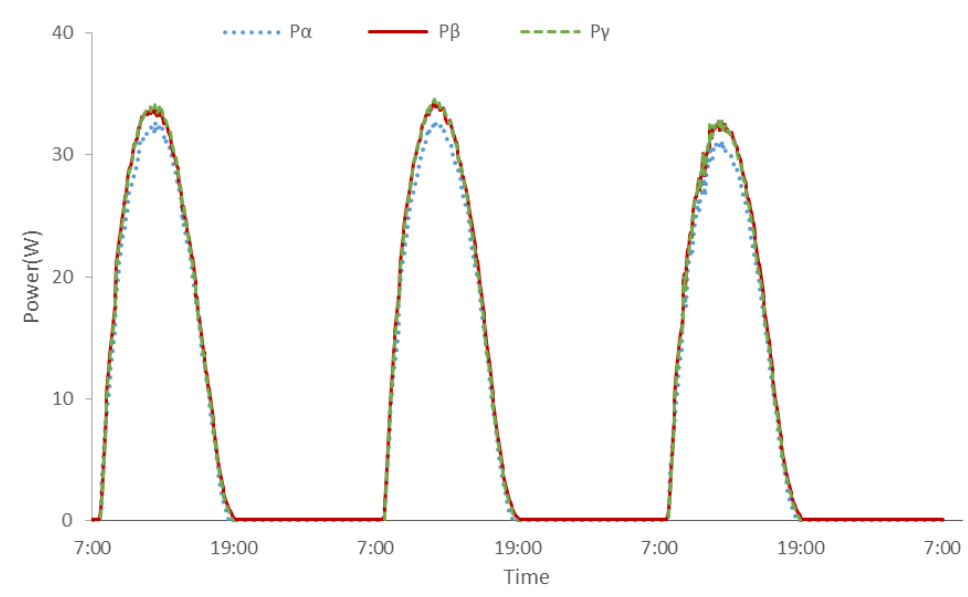

Figure 9. Power produced by reference PV panel $\left(P_{\alpha}\right)$, PV panel with PCM $\left(P_{\beta}\right)$ and PV-PCM with water circulation $\left(P_{\gamma}\right)$ for three consecutive days from 30 January 2015 to 2 February 2015 at the site of system deployment in Falaj Hazza Campus, UAE University, Al Ain, UAE. 
The total electrical energy produced, heat losses and the energy storage capacity of each of the module are summarized in Figure 10. It shows that the reference PV showed a highest heat loss $\left(Q_{1}\right)$ and lowest thermal energy storage capacity $\left(Q_{s}\right)$ while the PV-PCM and PV-PCM-W showed lower heat losses and higher thermal energy storage capacity. It can also be seen that the PV-PCM and PV-PCM-W produced higher electrical energy $\left(Q_{\mathrm{e}}\right)$ compared to that of the reference PV. Thus it can be concluded that the PV-PCM system can increase electrical output as well as thermal energy storage capacity of PV system due to temperature regulation and latent heat absorption in PCM.

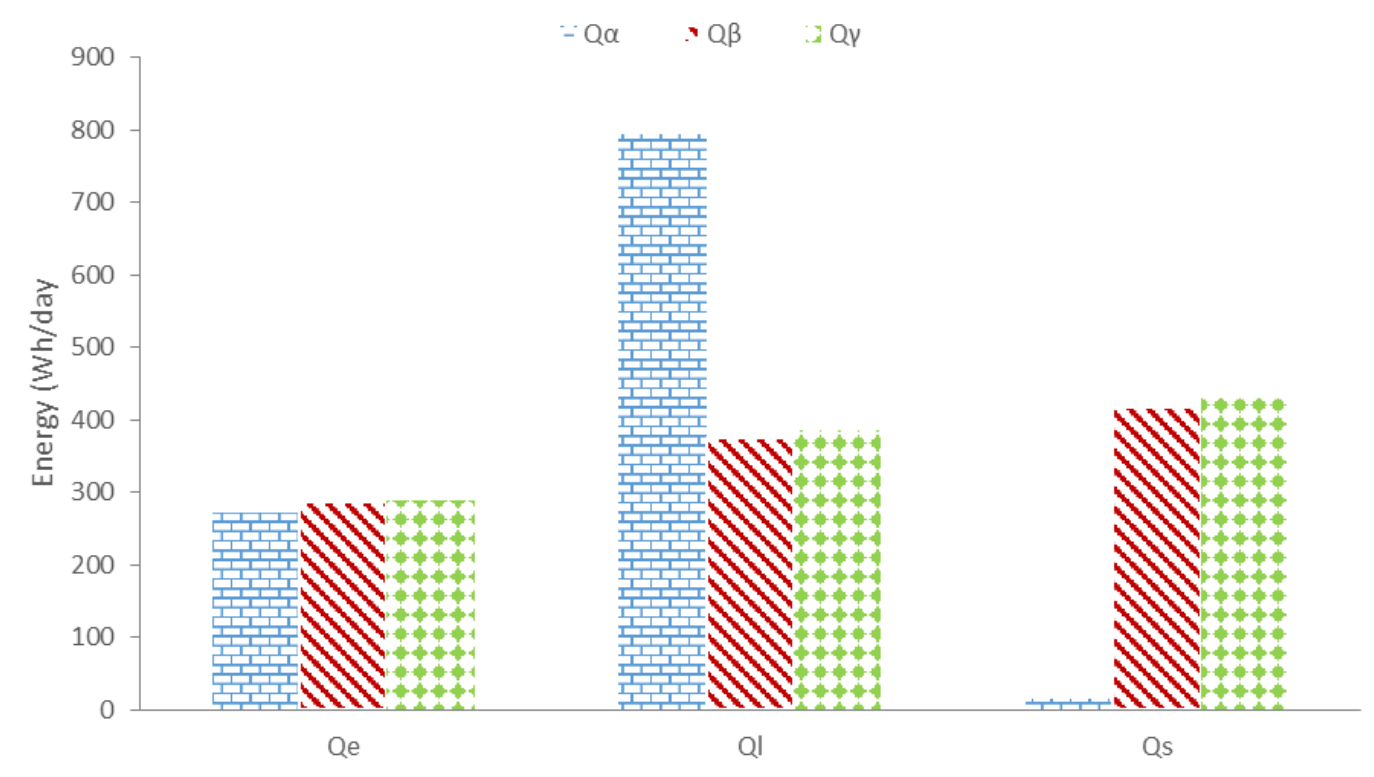

Figure 10. Electrical energy produced $\left(Q_{e}\right)$, heat losses $\left(Q_{1}\right)$ and thermal energy stored $\left(Q_{s}\right)$ for PV-Ref $\left(Q_{\alpha}\right)$ PV-PCM $\left(Q_{\beta}\right)$ and PV-PCM-W $\left(Q_{\gamma}\right)$ during three consecutive days from 30 January 2015 to 2 February 2015 measured at the site of system deployment in Falaj Hazza Campus, UAE University.

\section{Conclusions}

The proposed PV-PCM system with water circulation was evaluated for three winter days in $\mathrm{Al}$ Ain, UAE to regulate PV temperature and extract the stored thermal energy in the PCM. Inclusion of the PCM in the PV rendered a drop in PV front surface temperature (representative of PV cell temperature) of $9{ }^{\circ} \mathrm{C}$ at peak and $5{ }^{\circ} \mathrm{C}$ on the average. The tested PV-PCM system reduced heat losses by up to $435 \mathrm{kWh}$ /day which resulted an increased thermal energy storage capacity by the same amount compared to the PV without PCM. The stored energy is removed by water circulation which heated $50 \mathrm{~L}$ of water by $9^{\circ} \mathrm{C}$ from $29^{\circ} \mathrm{C}$ to $38^{\circ} \mathrm{C}$ thereby extracting $521 \mathrm{Wh} /$ day thermal energy. The achieved water temperature is appropriate for domestic hot water applications. Eventually, the proposed PV-PCM-W system increased the electrical performance by $\sim 6 \%$ (equivalent to an increase in PV efficiency of $\sim 1 \%$ ) and thermal performance by $\sim 41 \%$ compared to the available global solar irradiation.

Acknowledgments: The authors would like to acknowledge the financial support from UAE University through center based research grant number 31R040-Research center-ECEER-3-2014 and the College of Engineering for the facilities to conduct the research.

Author Contributions: Ahmad Hasan and Hamza Alnoman conceived and designed the experiments; Hamza Alnoman performed the experiments; Ahmad Hassan and Ali Hasan Shah analyzed the data; Hamza Alnouman contributed reagents/materials/analysis tools; Ali Hasan Shah wrote the paper.

Conflicts of Interest: The authors declare no conflict of interest. 


\section{Abbreviations}

$\begin{array}{ll}\text { BIPV } & \text { Building integrated photovoltaic } \\ \text { CHP } & \text { Combined heat and power } \\ \text { DSC } & \text { Differential scanning calorimetry } \\ \text { EVA } & \text { Ethylene vinyl acetate } \\ \text { PV } & \text { Photovoltaic } \\ \text { PVT } & \text { Hybrid photovoltaic thermal systems } \\ \text { PCM } & \text { Phase change material } \\ \text { PV-PCM } & \text { Photovoltaic-phase change material } \\ \text { PV-PCM-W } & \text { Photovoltaic-phase change material with water circulation } \\ \text { STC } & \text { Standard test conditions } \\ \text { W } & \text { Water } \\ \text { i } & \text { Initial state } \\ \text { f } & \text { Final state }\end{array}$

\section{Symbols}

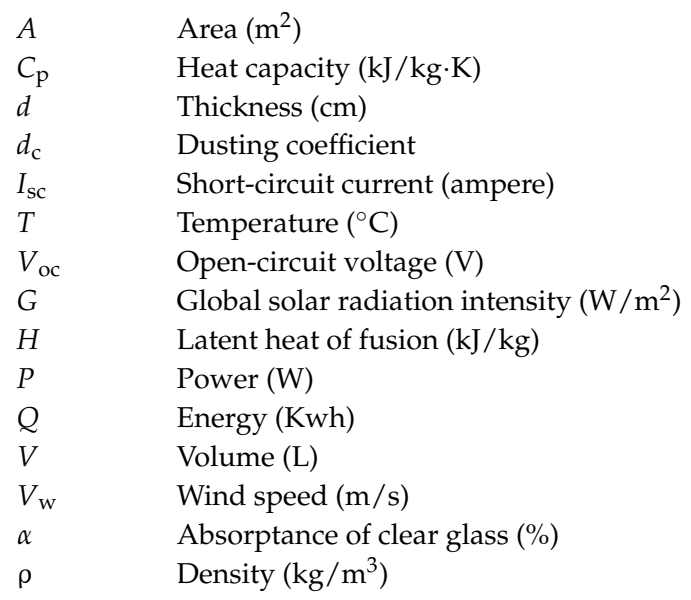

\section{Subscripts}

$\begin{array}{ll}\alpha & \text { Photovoltaic reference } \\ \beta & \text { Photovoltaic-phase change material } \\ \gamma & \text { Photovoltaic-phase change material with water circulation } \\ \mathrm{S} & \text { Stored energy } \\ \mathrm{e} & \text { Electrical energy } \\ \mathrm{b} & \text { Back surface } \\ \mathrm{l} & \text { Energy losses } \\ \mathrm{f} & \text { Front surface } \\ \mathrm{amb} & \text { Ambient } \\ \mathrm{m} & \text { Melting }\end{array}$

\section{References}

1. National Renewable Energy Laboratory. National Center for Photovoltaic. Available online: http://www. nrel.gov/ncpv/images/efficiency_chart.jpg (accessed on 3 March 2016).

2. Razykov, T.M.; Ferekides, C.S.; Morel, D.; Stefanakos, E.; Ullal, H.S.; Upadhyaya, H.M. Solar photovoltaic electricity: Current status and future prospects. Sol. Energy 2011, 85, 1580-1608. [CrossRef]

3. Santbergen, R.; van Zolingen, R.C. The absorption factor of crystalline silicon PV cells: A numerical and experimental study. Sol. Energy Mater. Sol. Cells 2008, 92, 432-444. [CrossRef]

4. Green, M.A. Solar Cells: Operating Principles, Technology, and System Applications; Prentice-Hall, Inc.: Englewood Cliffs, NJ, USA, 1982.

5. Jiang, B.; Ji, J.; Yi, H. The influence of PV coverage ratio on thermal and electrical performance of photovoltaic-Trombe wall. Renew. Energy 2008, 33, 2491-2498. [CrossRef] 
6. Sarwar, J.; McCormack, S.; Huang, M.J.; Norton, B. Numerical validation of experimental temperature evolution in photovoltaic cells with varying ambient conditions. Available online: http:/ /www.tara.tcd.ie/ bitstream/handle/2262/67168/PVSAT-7_095_Paper_Sarwar.pdf?sequence=1 (accessed on 1 August 2016).

7. Bücher, K. Site dependence of the energy collection of PV modules. Sol. Energy Mater. Sol. Cells 1997, 47, 85-94. [CrossRef]

8. Chenni, R.; Makhlouf, M.; Kerbache, T.; Bouzid, A. A detailed modeling method for photovoltaic cells. Energy 2007, 32, 1724-1730. [CrossRef]

9. Ceylan, İ.; Gürel, A.E.; Ergün, A.; Tabak, A. Performance analysis of a concentrated photovoltaic and thermal system. Sol. Energy 2016, 129, 217-223. [CrossRef]

10. Skoplaki, E.; Palyvos, J.A. Operating temperature of photovoltaic modules: A survey of pertinent correlations. Renew. Energy 2009, 34, 23-29. [CrossRef]

11. Radziemska, E. The effect of temperature on the power drop in crystalline silicon solar cells. Renew. Energy 2003, 28, 1-12. [CrossRef]

12. Emery, K.; Burdick, J.; Caiyem, Y.; Dunlavy, D.; Field, H.; Kroposki, B.; Moriarty, T.; Ottoson, L.; Rummel, S.; Strand, T.; et al. Temperature dependence of photovoltaic cells, modules and systems. In Proceedings of the Twenty Fifth IEEE Photovoltaic Specialists Conference, Washington, DC, USA, 13-17 May 1996; pp. 1275-1278.

13. Saga, T. Advances in crystalline silicon solar cell technology for industrial mass production. NPG Asia Mater. 2010, 2, 96-102. [CrossRef]

14. Furkan, D.; Mehmet Emin, M. Critical factors that affecting efficiency of solar cells. Smart Grid Renew. Energy 2010, 1, 47-50.

15. Kamkird, P.; Ketjoy, N.; Rakwichian, W.; Sukchai, S. Investigation on temperature coefficients of three types photovoltaic module technologies under Thailand operating condition. Procedia Eng. 2012, 32, 376-383. [CrossRef]

16. Skoplaki, E.; Boudouvis, A.G.; Palyvos, J.A. A simple correlation for the operating temperature of photovoltaic modules of arbitrary mounting. Sol. Energy Mater. Sol. Cells 2008, 92, 1393-1402. [CrossRef]

17. Kurtz, S.; Whitfield, K.; TamizhMani, G.; Koehl, M.; Miller, D.; Joyce, J.; Wohlgemuth, J.; Bosco, N.; Kempe, M.; Zgonena, T. Evaluation of high-temperature exposure of photovoltaic modules. Progr. Photovolt.: Res. Appl. 2011, 19, 954-965. [CrossRef]

18. Ružinsky, M.; Redi, P. Indoor study and ageing tests of solar cells and encapsulations of experimental modules. In Proceedings of the 24th International Spring Seminar on Electronics Technology: Concurrent Engineering in Electronic Packaging, Calimanesti-Caciulata, Romania, 5-9 May 2001.

19. Du, D.; Darkwa, J.; Kokogiannakis, G. Thermal management systems for Photovoltaics (PV) installations: A critical review. Sol. Energy 2013, 97, 238-254. [CrossRef]

20. Huang, M.J.; Eames, P.C.; Norton, B. Thermal regulation of building-integrated photovoltaics using phase change materials. Int. J. Heat Mass Transf. 2004, 47, 2715-2733. [CrossRef]

21. Hasan, A.; McCormack, S.J.; Huang, M.J.; Norton, B. Characterization of phase change materials for thermal control of photovoltaics using Differential Scanning Calorimetry and Temperature History Method. Energy Convers. Manag. 2014, 81, 322-329. [CrossRef]

22. Huang, M.J.; Eames, P.C.; Norton, B. Phase change materials for limiting temperature rise in building integrated photovoltaics. Sol. Energy 2006, 80, 1121-1130. [CrossRef]

23. Huang, M.J. The effect of using two PCMs on the thermal regulation performance of BIPV systems. Sol. Energy Mater. Sol. Cells 2011, 95, 957-963. [CrossRef]

24. Hasan, A.; McCormack, S.J.; Huang, M.J.; Norton, B. Evaluation of phase change materials for thermal regulation enhancement of building integrated photovoltaics. Sol. Energy 2010, 84, 1601-1612. [CrossRef]

25. Kibria, M.A.; Saidur, R.; Al-Sulaiman, F.A.; Aziz, M.M.A. Development of a thermal model for a hybrid photovoltaic module and phase change materials storage integrated in buildings. Sol. Energy 2016, 124, 114-123. [CrossRef]

26. Sharma, S.; Tahir, A.; Reddy, K.S.; Mallick, T.K. Performance enhancement of a Building-Integrated Concentrating Photovoltaic system using phase change material. Sol. Energy Mater. Sol. Cells 2016, 149, 29-39. [CrossRef] 
27. Hasan, A.; McCormack, S.J.; Huang, M.J.; Sarwar, J.; Norton, B. Increased photovoltaic performance through temperature regulation by phase change materials: Materials comparison in different climates. Sol. Energy 2015, 115, 264-276. [CrossRef]

28. Browne, M.C.; Norton, B.; Mc Cormack, S.J. Phase change materials for photovoltaic thermal management. Renew. Sustain. Energy Rev. 2015, 47, 762-782. [CrossRef]

29. Hasan, A.; McCormack, S.J.; Huang, M.J.; Norton, B. Energy and cost saving of a photovoltaic-phase change materials (PV-PCM) system through temperature regulation and performance enhancement of photovoltaics. Energies 2014, 7, 1318-1331. [CrossRef]

30. Ma, T.; Yang, H.; Zhang, Y.; Lu, L.; Wang, X. Using phase change materials in photovoltaic systems for thermal regulation and electrical efficiency improvement: A review and outlook. Renew. Sustain. Energy Rev. 2015, 43, 1273-1284. [CrossRef]

31. Professional Plastics. Thermal Properties of Plastic Materials. Available online: http://www.professionalplastics. com/professionalplastics/ThermalPropertiesofPlasticMaterials.pdf (accessed on 26 March 2016).

32. Apogee Instruments. SP-110: Self-Powered Pyranometer. Available online: http://www.apogeeinstruments. co.uk/sp-110-self-powered-pyranometer/ (accessed on 3 August 2016).

33. Tmart. WS1041 Professional Weather Station with PC Link. Available online: http://www.tmart.com/ WS1041-Professional-Weather-Station-with-PC-Link_p238349.html (accessed on 27 March 2016).

34. Apogee Instruments. Specification Sheet. Available online: http://www.apogeeinstruments.co.uk/content/ SP-100-200-spec-sheet.pdf (accessed on 13 March 2016).

35. National Instruments. NI cRIO-9073. National Instruments. Available online: http://www.ni.com/pdf/ manuals/374639f.pdf (accessed on 3 August 2016).

36. National Instruments, NI 9227. Available online: http://sine.ni.com/nips/cds/view/p/lang/en/nid/ 208794 (accessed on 15 March 2016).

37. National Instruments, NI 9213. Available online: http://sine.ni.com/nips/cds/view/p/lang/en/nid/ 208788 (accessed on 15 March 2016).

38. WS1041 Professional Weather Station w/ PC Link. Available online: http://www.dx.com/p/ws1041professional-weather-station-w-pc-link-275697\#.Vvf3Q9J97IU (accessed on 27 March 2016).

39. National Instruments, Data Sheet NI 9221. Available online: http://www.ni.com/pdf/manuals/375905a_02. pdf (accessed on 31 March 2016).

40. Rubitherm. Available online: http://www.rubitherm.eu/media/products/datasheets/Techdata_-RT42_ EN_09052016.PDF (accessed on 3 August 2016).

41. International Programme on Chemical Safety. POLYSTYRENE. Available online: http://www.inchem.org/ documents/icsc/icsc/eics1043.htm (accessed on 16 February 2016).

42. Aalco Metals Ltd. Aluminium Alloy 1050A H14 Sheet. Available online: http://www.aalco.co.uk/datasheets/ Aalco-Metals-Ltd_Aluminium-Alloy-1050A-H14-Sheet_57.pdf.ashx (accessed on 3 August 2016).

43. Electrolube. ER2074 Epoxy Resin Technical Data Sheet. Available online: http://datasheet.octopart.com/ ER2074RP250G-Electrolube-datasheet-537902.pdf (accessed on 17 March 2016).

44. Tiwari, A.; Sodha, M.S. Performance evaluation of solar PV/T system: An experimental validation. Sol. Energy 2006, 80, 751-759. [CrossRef]

45. Jones, A.D.; Underwood, C.P. A thermal model for photovoltaic systems. Sol. Energy 2001, 70, 349-359. [CrossRef]

46. Browne, M.C.; Norton, B.; Mccormack, S.J. Heat retention of a photovoltaic/thermal collector with PCM. Sol. Energy 2016, 133, 533-548. [CrossRef]

(C) 2016 by the authors; licensee MDPI, Basel, Switzerland. This article is an open access article distributed under the terms and conditions of the Creative Commons Attribution (CC-BY) license (http://creativecommons.org/licenses/by/4.0/). 